\title{
Quality of Cambuci pepper seedlings in response to the application of nutrient solutions
}

\author{
Nicholas Taborda Nordi ${ }^{1}$, Eduardo Santana Aires ${ }^{1}$, Thatiane Nepomuceno Alves ${ }^{1}$, Samara \\ Moreira Perisato ${ }^{1}$, Antonio Ismael Inácio Cardoso ${ }^{1}$
}

\begin{abstract}
${ }^{1}$ Universidade Estadual Paulista "Júlio de Mesquita Filho", Faculdade de Ciências Agronômicas, Campus de Botucatu, Botucatu, São Paulo, Brasil. E-mail: nicholasnordi@hotmail.com, aires-eduardo@live.com, thatinepomuceno@hotmail.com, samaraperissato@gmail.com, antonio-ismael.cardoso@unesp.br
\end{abstract}

Received: 27/04/2020; Accepted: 06/08/2020.

\section{ABSTRACT}

One of the main stages in the production system of a crop is the production of quality seedlings since it influences the plants' final performance in the field and their production. The study aimed to evaluate different nutrient solutions in the production of Cambuci pepper seedlings. The design used was a complete randomized design, with six treatments corresponding to the nutrient solutions proposed for the pepper crop by Castellane and Araújo, Claudio Roberto, Hoagland, and Arnon, besides the commercial products Plenan ${ }^{\circledR}$ and Biobokashi ${ }^{\circledR}$, and a control treatment without fertilization, with six replications. The final evaluation was carried out 45 days after sowing. The following variables were analyzed: stem diameter, plant height, leaf dry matter, shoot dry matter, the number of leaves, relative chlorophyll index ("Spad"), and Dickson quality index. The seedlings subjected to the applications of Claudio Roberto and Hoagland and Arnon solutions have the highest heights and number of leaves, the largest stem diameter, shoot dry matter, leaf area, and Dickson quality index with 2.60 and $2.51 \mathrm{~mm}, 0.54$ and $0.62 \mathrm{~g}$, 38.64 and $41.91 \mathrm{~cm}^{2}$, and $0.107 ; 0.097$, respectively. The Hoagland and Arnon nutrient solution provided the best characteristics to produce Cambuci pepper seedlings.

Keywords: Capsicum baccatum, fertilization, seedling growth.

\section{Qualidade de mudas de pimenta Cambuci em resposta a aplicação de soluções nutritivas}

\section{RESUMO}

Uma das principais etapas no sistema produtivo de uma cultura é a produção de mudas de qualidade, pois delas depende o desempenho final das plantas no campo e a sua produção. O objetivo da pesquisa foi avaliar diferentes soluções nutritivas na produção de mudas de pimenta Cambuci. O delineamento utilizado foi o inteiramente casualizado, com seis tratamentos correspondentes a soluções nutritivas propostas para a cultura do pimentão por Castellane e Araújo, Claudio Roberto, Hoagland e Arnon, além dos produtos comerciais Plenan ${ }^{\circledR}$ e Biobokashi ${ }^{\circledR}$, e uma testemunha sem adubação, com seis repetições. A avaliação final foi realizada aos 45 dias após a semeadura, sendo analisadas as seguintes variáveis: diâmetro do colo, altura da planta, massa seca da folha e de parte aérea, número de folhas, índice relativo de clorofila ("Spad") e índice de qualidade de Dickson. As mudas submetidas às aplicações das soluções Claudio Roberto e Hoagland e Arnon apresentaram as maiores alturas e número de folhas, maior diâmetro do colo, massa seca de parte aérea, área foliar e índice de qualidade com 2,60 e 2,51 mm, 0,54 e 0,62 g e 38,64 e 41,91 cm, e 0,107; 0,097, respectivamente. A solução nutritiva de Hoagland e Arnon foi a que proporcionou melhores características para a produção de mudas de pimenta Cambuci.

Palavras-chave: Capsicum baccatum, adubação, crescimento de plântulas. 


\section{Introduction}

The total area with vegetables reproduced by seeds in Brazil represents about 840 thousand hectares, generating approximately 2 million direct jobs, that is, 2.4 jobs ha-1 (ABCSEM, 2014). Among the vegetables grown, pepper has great importance and appreciation in Brazilian cuisine. The Capsicum genus comprises more than 200 cataloged species, with variations of fruits in their shape, size, flavor, and sensory heat. Five main species are cited in the literature: Capsicum annuиm, Capsicum baccatum, Capsicum chinense, Capsicum frutescens, and Capsicum pubescens (Zimmer et al., 2012). Peppers of the genus Capsicum originate from Central and South America, native to tropical and humid areas. They belong to the Solanaceae family, which includes peppers of important economic value (Govindarajan and Salzer, 1986; Menichini et al., 2009).

The species $C$. baccatum L. is subdivided into four botanical varieties: pêndulo (wild), Eshbaugh; baccatum, praetermissum (Heiser and PG Sm.) Hunz; E. umbilicatum (Vell.) Hunz. and Barboza (Albrecht et al., 2012). The base of each corolla lobe has spots of yellowish or greenish color, thus differing from the other species of Capsicum (Carvalho and Bianchetti, 2008).

The wild variety is represented by the morphological types "Dedo-de-moça", which is very popular in Brazilian cuisine, and Cambuci (Fonseca et al., 2008; Costa et al., 2016). "Dedo-de-moça" peppers have a delicate shape and resemble a woman's finger, from which their common name arises. Cambuci peppers are found in northeastern South America, including Colombia, Ecuador, Peru, Bolivia, and South and Southeast Brazil, known as the "Chapéu-de-Bispo" or "Chapéu-de-Frade" and are not pungent. The morphological types of this vegetable variety are used in different ethnic categories, such as food, spices, medicinal, ornamental; religious, and other diverse applications (Pasa et al., 2017).

One of the main stages in a crop's production system is the production of quality seedlings, as the final performance of plants in the field and their production depends on them (Maciel et al., 2017). For the production of quality seedlings, the use of techniques and inputs assists the process and optimizes production costs, reducing expenses and guaranteeing a final product according to the required standards (Santos et al., 2000). Studies such as those by Miqueloni et al. (2013) show that the size of the tubes in the production of seedlings had significant importance in the development of seedlings according to their morphological characteristics. Oliveira et al. (2012) found that the use of domestic wastewater emerges as an economically viable alternative for the use in the irrigation of pepper seedling nurseries, as well as the use of commercial substrate Carolina Soil ${ }^{\circledR}$ if showed more suitable for the production of pepper and bell pepper seedlings (Silva et al., 2019).

Correct management and the type of substrate, whether conventional or alternative, have a significant influence on forming the root system of plants and, therefore, can interfere with nutritional status and production (Minami, 2010). The use of alternative substrates in the production of seedlings has been increasing considerably by vegetable producers who preferentially seek alternatives to reduce costs and maintain yield and quality (Nadai et al., 2015). The alternative substrate is usually derived from raw materials available close to the cultivation sites (Costa et al., 2013). It may be of vegetable and/or animal origin with emphasis on manure and earthworm humus, as they provide nutrients and have a reduced cost (Diniz et al., 2006).

Besides the mixture of substrates, nutrient supplementation can be used to assist in the production of vigorous seedlings that are less susceptible to damage caused during transplanting and, also, to enable better crop performance in the soil (Bezerra, 2003). However, some factors must be considered to successfully use fertigation in the production of seedlings, such as the concentration of nutrients in the nutrient solution and frequency of application of nutrients (Ciavatta et al., 2014).

The Carolina Soil ${ }^{\circledR}$ substrate has unsatisfactory amounts of nutrients for seedling development, thus making nutrient solutions essential to provide the ideal amount for development. This supplementation can be done by adding nutrients to the substrate at its formulation or through fertigation with nutrient solution. Fertigation consists of applying fertilizers via irrigation water. This technique provides increased efficiency of nutrient absorption, installment of fertilization according to its absorption by the plant, and labor and energy savings (Oliveira et al., 2016).

In the production of seedlings in trays, which have little substrate volume for each seedling, fertigation is a necessity, especially in species with longer seedling production time, such as peppers. Given the above, the study aimed to evaluate the influence of different nutritional solutions on Cambuci pepper seedlings production.

\section{Material and Methods}

The experiment was conducted from April to June 2019, in a greenhouse, at the Department of Forestry Sciences of the School of Agronomic Sciences (FCA), the Sao Paulo State University (UNESP), in BotucatuSP. The region, according to the Köppen classification, has a humid warm (mesothermal) temperate climate, 
with rain in the summer and drought in the winter, the average temperature of the coldest month is below $17^{\circ} \mathrm{C}$, and the hottest is above $23{ }^{\circ} \mathrm{C}$, with monthly rainfall greater than $30 \mathrm{~mm}$ (Cunha and Martins, 2009).

The design used was completely randomized, with six treatments corresponding to nutritional solutions proposed for the pepper culture by Castellane and Araújo (1995), a formulation adapted by the Claudio Roberto, University employee, based on that of Castellane and Araújo (1995), Hoagland and Arnon (1950), in addition to the commercial products Plenan ${ }^{\circledR}$ and Biobokashi ${ }^{\circledR}$, and control without fertilization, with six replications. The chemical composition of each treatment is shown in Table 1. For the use of the Plenan ${ }^{\circledR}$ formulation, the mixture of Plenan ${ }^{\circledR} 1$ and 2 products were used in the formulation of $1 \mathrm{ml}$ of each product for each liter of water. Biobokashi ${ }^{\circledR}$ was used at a concentration of $5 \mathrm{~mL} / \mathrm{L}$ of water.

The seedlings were produced in polypropylene trays with 200 cells, a volume of $18 \mathrm{~cm}^{3}$, using the substrate Carolina Soil. Sowing was carried out on 05/08/2019, placing two seeds per cell, and three days after emergence, thinning was carried out, leaving one plant per cell; five lines with ten cells were maintained for each plot, followed by two empty lines. Of the five lines, the first and the last were considered as borders and the first and the last columns, with 24 central seedlings being considered a useful plot.

In the experimental period, the micro-sprinkler system carried out irrigations in two irrigations per day: morning and afternoon. The treatments were applied twice a week, using $500 \mathrm{~mL}$ of nutrient solution for each plot. A fine screen watering can was used to apply the solutions.
Plant height $(\mathrm{cm})$ and total dry matter $(\mathrm{g})$, including leaves, stems, and roots, were evaluated weekly, with the first evaluation being seven days after emergence (DAE) and the last at 35 DAE. For these evaluations, three plants were used per replication.

The final evaluation was carried out at 45 DAE. The following variables were analyzed: stem diameter ( $\mathrm{mm})$ (SD), plant height $(\mathrm{cm})(\mathrm{PH})$, number of final leaves $(\mathrm{NL})$, leaf area $\left(\mathrm{cm}^{2}\right)(\mathrm{LA})$, relative chlorophyll index (SPAD index) (performed in two points per fully expanded leaf, the average of which is used to represent the value of each plot), leaf dry matter (g) (LDM), shoot dry matter (leaves + stem) (g) (SDM), and Dickson's quality index (DQI).

The seedlings were separated into leaf, stem, and root, packed in paper bags for drying in a forced air circulation oven for 72 hours, with temperature ranging from 65 to $70{ }^{\circ} \mathrm{C}$, being weighed in a precision analytical balance $(0.001 \mathrm{~g})$. Leaf dry matter and total dry matter (TDM) were expressed in g.plant ${ }^{-1}$. The leaf area (LA) was obtained using an Area Meter area integrator, model Li-3100 from Li-Cor, and expressed in $\mathrm{cm}^{2}$.

$O$ The DQI was determined using the following equation (Dickson et al., 1960):

$$
D Q I=\frac{T D M(g)}{\frac{P H(\mathrm{~cm})}{S D(\mathrm{~mm})}+\frac{S D M(\mathrm{~g})}{R D M(\mathrm{~g})}}
$$

The data obtained were subjected to analysis of variance. The averages resulting from the treatments were grouped by applying the Scott-Knott test at the level of $5 \%$ probability, with the aid of the Agroestat $^{\circledR}$ statistical software.

Table 1. Chemical characterization of solutions applied to Cambuci pepper seedlings. Botucatu-SP, 2019.

\begin{tabular}{|c|c|c|c|c|c|c|}
\hline \multirow[b]{2}{*}{ Nutrients } & Castellane and Araújo & Claudio Roberto & Hoagland and Arnon & $\begin{array}{c}\text { Plenan Ferti } \\
\text { PM1 }\end{array}$ & $\begin{array}{c}\text { Plenan Ferti } \\
\text { PM2 }\end{array}$ & Biobokashi \\
\hline & \multicolumn{6}{|c|}{$\mathrm{mg} . \mathrm{L}^{-1}$} \\
\hline Nitrogen & $152 *$ & 210 & 445.2 & 880 & 66810 & 1000 \\
\hline Phosphor & 29 & 31 & 119.6 & 83640 & & \\
\hline Potassium & 245 & 230 & 396 & 82730 & 26060 & 6530 \\
\hline Calcium & 20 & 160 & 361 & - & 41600 & 23920 \\
\hline Magnesium & 32 & 48 & 79.2 & 17820 & - & - \\
\hline Sulfur & - & 75 & 162.8 & 82730 & 24 & - \\
\hline Molybdenum & - & - & - & - & 41600 & - \\
\hline Boron & - & - & - & - & 272 & - \\
\hline Copper & - & - & & - & 1090 & - \\
\hline Iron & - & - & - & - & 272 & 1076 \\
\hline Manganese & - & - & - & - & 1090 & - \\
\hline Zinc & - & - & - & - & 110 & 440 \\
\hline Nickel & - & - & - & - & 62 & - \\
\hline Organic carbon & - & - & - & - & - & 8000 \\
\hline
\end{tabular}




\section{Results and Discussion}

From the analysis of variance, it was possible to verify that there were significant differences in plant height and dry matter (Table 2). It was observed that until the $2^{\text {nd }}$ week after sowing, there was no significant difference for plant height and leaf dry matter between the solutions and the control. In the initial phase, the seedlings show slower growth, and the vegetative organs are still developing, mainly the leaves. According to Marcos-Filho (2015), the growth of plants is provided by photosynthesis, which is performed basically by leaves. In the initial phase, by cotyledons, with nutrition being less important in this stage than the seed reserves.

In the third week, the plants of all the tested solutions had a higher height and leaf dry matter than the control without fertilization (Table 2). In the fourth week, only treatment with Biobokashi ${ }^{\circledR}$ did not differ from the control. For Biobokashi ${ }^{\circledR}$, compared to the other solutions, growth was slower, justified by the slower release of nutrients to the seedlings (Benício et al., 2011). There was no interaction between the variables analyzed. It can be seen in Figure 1A and 1B that the polynomial model that best fitted all treatments was the quadratic model, with the highest values obtained after the $7^{\text {th }}$ day, a period when the plant began to accumulate a greater amount of dry matter.

The nutrient solution of Claudio Roberto showed the fastest growth, followed by Hogland and Arnon, Plenan, and Castellane and Araujo, with minimum points varying between 1.22 to $1.43 \mathrm{~cm}$ from the 7th day. The largest accumulation of dry matter occurred after 25 days after emergence (Figure 1B). During this phase of crop growth, the seedlings already had definitive leaves in development and, consequently, greater dry matter accumulation.
A significant effect was observed by the $\mathrm{F}$ test $(\mathrm{p}$ $<0.05)$ for all variables analyzed at 45 DAE. The seedlings submitted to the application of the solutions of Castellane and Araújo, Claudio Roberto, Plenan ${ }^{\circledR}$, and Hoagland and Arnon presented height higher than the control, without statistical difference between them, with averages of $7.14 \mathrm{~cm}, 8.27 \mathrm{~cm}, 7.66 \mathrm{~cm}$, and 8.04 $\mathrm{cm}$, respectively (Table 3 ). The seedlings submitted to the solutions of Claudio Roberto and Hoagland and Arnon presented a larger stem diameter, with 2.60 and $2.51 \mathrm{~mm}$, respectively, not differing from each other, as well as Plenan ${ }^{\circledR}$ and Castellane and Araújo, which did not differ from each other, but differed from the control.

As a result, the treatments applied showed higher values than the control regarding plant height, except for applying the Biobokashi ${ }^{\circledR}$ product. For Souza et al. (2013), the parameters plant height and stem diameter are the most important morphological components for estimating seedling growth; however, these attributes alone are not sufficient to determine the quality of the seedling, as seedlings with a higher height may show breakdown, for example.

When compared the concentrations of each nutrient in the applied treatments (Table 1), it is noted that the two treatments (Claudio Roberto and Hoagland and Arnon) that presented higher values have a higher nitrogen content compared to the other formulations studied. Silva et al. (2018), studying the effect of nitrogen and potassium doses on the production of broccoli seedlings, observed higher values of plant height, stem diameter, and shoot dry matter when applied the highest dose of $\mathrm{N}\left(240 \mathrm{mg} . \mathrm{L}^{-1}\right)$. Cardoso et al. (2017) reported a linear increase in the vegetative traits of Chinese cabbage (Brassica pekinensis) seedlings, the higher the applied nitrogen dose.

Table 2. Plant height (PH) and leaf dry matter (LDM) of Cambuci pepper according to different nutrient solutions during the weeks evaluated. Botucatu-SP, 2019.

\begin{tabular}{|c|c|c|c|c|c|c|c|c|}
\hline Treatment & Control & $\begin{array}{l}\text { Castellane } \\
\text { and Araújo }\end{array}$ & $\begin{array}{l}\text { Claudio } \\
\text { Roberto }\end{array}$ & Plenan $^{\circledR}$ & $\begin{array}{c}\text { Hoagland and } \\
\text { Arnon }\end{array}$ & Biobokashi $^{\circledR}$ & $\mathrm{CV} \%$ & SEM \\
\hline \multicolumn{9}{|c|}{$1^{\mathrm{a}}$ evaluation } \\
\hline $\mathrm{PH}$ & $1.2600 \mathbf{a}$ & $1.2600 \mathbf{a}$ & $1.2600 \mathbf{a}$ & $1.2600 \mathbf{a}$ & $1.2600 \mathbf{a}$ & $1.2600 \mathbf{a}$ & 0 & 0 \\
\hline LDM & $0.0039 \mathbf{a}$ & $0.0039 \mathbf{a}$ & $0.0039 \mathbf{a}$ & $0.0039 \mathbf{a}$ & $0.0039 \mathbf{a}$ & $0.0039 \mathbf{a}$ & 0 & 0 \\
\hline \multicolumn{9}{|c|}{$2^{\mathrm{a}}$ evaluation } \\
\hline $\mathrm{PH}$ & $2.5580 \mathbf{a}$ & $2.5250 \mathrm{a}$ & $2.6670 \mathbf{a}$ & $2.4670 \mathbf{a}$ & $2.6670 \mathbf{a}$ & $2.6170 \mathbf{a}$ & 8.01 & 0.084 \\
\hline LDM & $0.0392 \mathbf{a}$ & $0.0394 \mathbf{a}$ & $0.0460 \mathbf{a}$ & $0.0338 \mathbf{a}$ & $0.0451 \mathbf{a}$ & $0.0393 \mathbf{a}$ & 18.19 & 0.003 \\
\hline \multicolumn{9}{|c|}{$3^{\mathrm{a}}$ evaluation } \\
\hline $\mathrm{PH}$ & $2.6300 \mathrm{~b}$ & $3.3700 \mathbf{a}$ & $3.5700 \mathbf{a}$ & $3.2700 \mathbf{a}$ & $3.6700 \mathbf{a}$ & $3.2200 \mathbf{a}$ & 12.36 & 0.166 \\
\hline LDM & $0.0652 \mathbf{b}$ & $0.0880 \mathbf{a}$ & $0.0861 \mathbf{a}$ & $0.0944 \mathbf{a}$ & $0.1040 \mathbf{a}$ & $0.0789 \mathbf{a}$ & 23.97 & 0.008 \\
\hline \multicolumn{9}{|c|}{$4^{\mathrm{a}}$ evaluation } \\
\hline $\mathrm{PH}$ & 3.4917 b & $4.4000 \mathbf{a}$ & $4.8000 \mathbf{a}$ & $4.6917 \mathbf{a}$ & $4.4917 \mathbf{a}$ & $3.7583 \mathrm{a}$ & 14.34 & 0.250 \\
\hline LDM & $0.1576 \mathbf{b}$ & $0.2146 \mathbf{a}$ & $0.2178 \mathbf{a}$ & $0.2173 \mathbf{a}$ & $0.2137 \mathbf{a}$ & $0.1474 \mathbf{b}$ & 22.41 & 0.018 \\
\hline
\end{tabular}

CV\% Coefficient of variation, *** SEM- Standard error of the mean. Values followed by the same letter, in the lines, belong to the same group by the Scott-Knott test at $5 \%$ probability. 

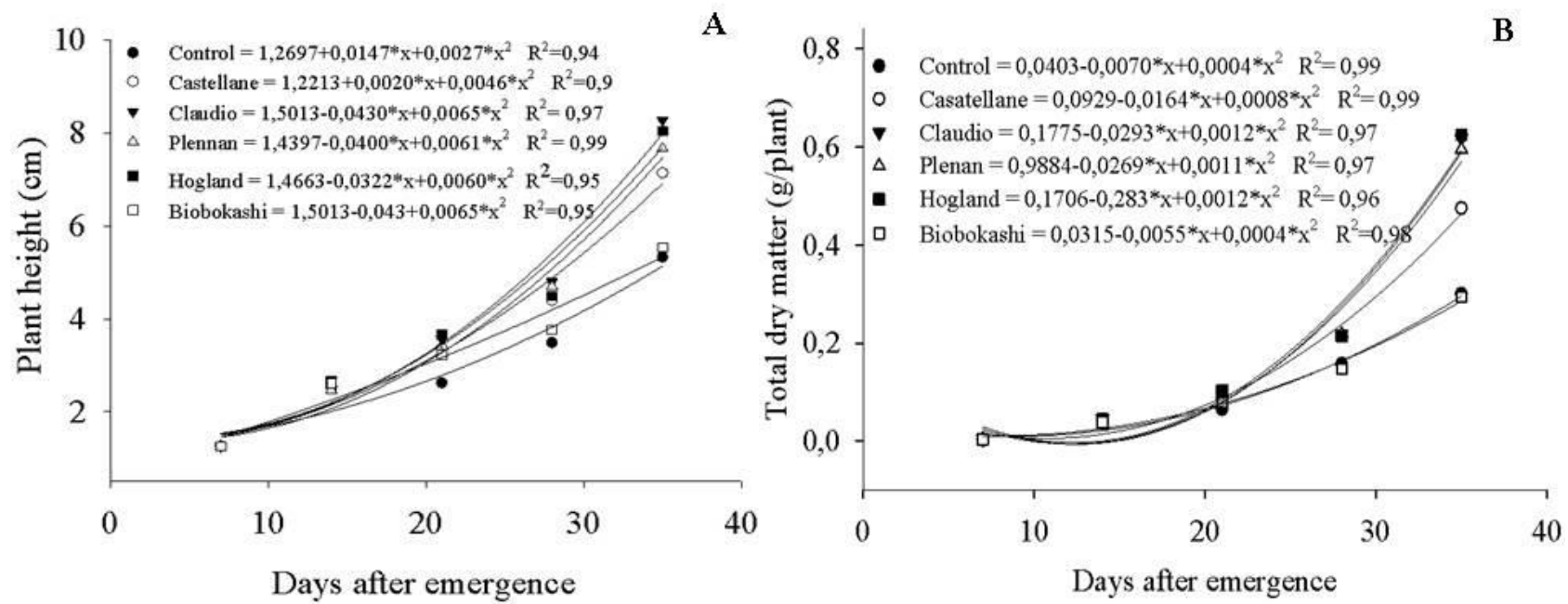

Figure 1. Plant height (A) and leaf dry matter (B) of Cambuci pepper according to different nutrient solutions. Botucatu-SP, 2019.

Table 3. Average values of stem diameter (SD), plant height (PH), number of leaves (NL), leaf area (LA), SPAD index, leaf dry matter (LDM), shoot dry matter (SDM), and Dickson quality index (DQI) of Cambuci pepper seedlings according to different nutrient solutions. Botucatu-SP, 2019.

\begin{tabular}{|c|c|c|c|c|c|c|c|c|}
\hline \multirow{2}{*}{ Treatments } & SD & $\mathrm{PH}$ & NL & LA & LDM & SDM & SPAD & DQI \\
\hline & $(\mathrm{mm})$ & $(\mathrm{cm})$ & unit & $\mathrm{cm}^{2}$ & (g) & (g) & & \\
\hline Control & $1.82 \mathrm{c}$ & $5.32 \mathbf{b}$ & $5.01 \mathrm{~b}$ & $22.54 \mathrm{c}$ & $0.20 \mathrm{~d}$ & $0.30 \mathbf{c}$ & $34.16 \mathbf{a}$ & $0.062 \mathrm{c}$ \\
\hline Castellane and Araújo & $2.25 \mathrm{~b}$ & $7.14 \mathbf{a}$ & $5.76 \mathbf{a}$ & $34.57 \mathbf{b}$ & $0.25 \mathrm{c}$ & $0.42 \mathbf{b}$ & $29.46 \mathbf{b}$ & $0.077 \mathbf{b}$ \\
\hline Claudio Roberto & $2.60 \mathbf{a}$ & $8.27 \mathbf{a}$ & $6.43 \mathbf{a}$ & $38.64 \mathbf{a}$ & $0.30 \mathbf{b}$ & $0.54 \mathbf{a}$ & $27.98 \mathbf{b}$ & $0.097 \mathbf{a}$ \\
\hline Plenan $^{\circledR}$ & $2.30 \mathbf{b}$ & $7.66 \mathbf{a}$ & $6.01 \mathbf{a}$ & $35.06 \mathbf{b}$ & $0.26 \mathrm{c}$ & $0.45 \mathbf{b}$ & $34.55 \mathrm{a}$ & $0.099 \mathbf{a}$ \\
\hline Hoagland and Arnon & $2.51 \mathbf{a}$ & $8.04 \mathbf{a}$ & $6.11 \mathbf{a}$ & $41.91 \mathbf{a}$ & $0.36 \mathbf{a}$ & $0.62 \mathbf{a}$ & $33.50 \mathbf{a}$ & $0.107 \mathbf{a}$ \\
\hline Biobokashi ${ }^{\circledR}$ & $1.76 \mathrm{c}$ & $5.54 \mathbf{b}$ & $5.23 \mathbf{b}$ & $25.15 \mathbf{c}$ & $0.17 \mathbf{d}$ & $0.29 \mathbf{c}$ & $33.88 \mathbf{a}$ & $0.050 \mathbf{c}$ \\
\hline$F^{*}$ & $26.4 * *$ & $17.9^{* *}$ & $6.34 * *$ & $8.79 * *$ & $9.66 * *$ & $19.8 * *$ & $18.1 * *$ & $12.2 * *$ \\
\hline SEM*** & 0.067 & 0.030 & 0.215 & 0.878 & 0.022 & 0.029 & 0.656 & 0.006 \\
\hline $\mathrm{CV}(\%)$ & 7.5 & 10.52 & 9.17 & 9.95 & 19.20 & 16.40 & 4.98 & 19.24 \\
\hline
\end{tabular}

* F - F calculated, ** Significant at 5\% probability, *** SEM - Standard error of the mean. Values followed by the same letter, in the columns, belong to the same group by the Scott-Knott test at $5 \%$ probability.

For the Hoagland and Arnon nutrient solution, the leaf dry matter showed a higher value $(0.36 \mathrm{~g})$ than the others (Table 3). As for the shoot dry matter, the solutions of Hoagland and Arnon and Claudio Roberto did not differ statistically, with values of $0.62 \mathrm{~g}$ and $0.54 \mathrm{~g}$, respectively, and were higher than the others.

In literature, there is no recommendation for the height of the Cambuci pepper seedling for transplanting to the field; nevertheless, for bell peppers, a height greater than $7 \mathrm{~cm}$ and the presence of four leaves is recommended (Filgueira, 2008). Therefore, the values obtained were higher than that recommended for bell pepper, with the highest values observed in the plants where the solutions of Castellane and Araujo, Claudio Roberto, Plenan ${ }^{\circledR}$, and Hoagland and Arnon were applied (Table 3). Oliveira et al. (2014), studying the effect of different concentrations of nutrient solutions in pepper seedlings production, observed a great variation in the height of the seedlings of different types of pepper, from $2.34 \mathrm{~cm}$ for Cheiro de Luna pepper to 9.31 $\mathrm{cm}$ for Doce Comprida. Thus, the values observed in the present research are among those verified by these authors, indicating that at 35 DAE, the seedlings could already be taken to the field.

From the leaf area results, the highest values are observed when the seedlings were fertigated with the solutions of Hoagland and Arnon and Claudio Roberto, $41.91 \mathrm{~cm}^{2}$ and $38.64 \mathrm{~cm}^{2}$, respectively. The greater the dry matter of the leaf and the leaf area in a plant, the greater its capacity to capture light energy and, consequently, photosynthesis, resulting in a greater accumulation of carbohydrates that, when the seedlings are taken to the field, will be used for the best development of the plant.

For the Dickson quality index (DQI), the best results were obtained when the solutions of Hogland and Arnon, Claudio Roberto, and the product Plenan ${ }^{\circledR}$ were applied. Biobokashi ${ }^{\circledR}$, a product that can be used by farmers who produce organic vegetables, did not show good results to produce Cambuci pepper seedlings in the evaluated dose.

The seeds have enough reserves and phytohormones to trigger the embryo's development to the seedling (Salisbury and Ross, 2013. From the beginning of the 
photosynthetic process of seedling and acceleration of growth, the supply of nutrients triggers a rapid development of plants, when compared to those that did not receive nutrients, a fact observed in the present research, considering that the applied elements are essential for the plant performs important functions, from cell wall structure, osmotic regulation, structural elements of proteins, nucleotides, lipids, enzyme activators, among others (Kerbauy, 2013).

Thus, the application of the nutrient solution proposed by Hoagland and Arnon (1950) and Claudio Roberto provided more vigorous seedlings of Cambuci pepper, as it increased the diameter of the stem, the height of the plants, as well as the leaf area (LA) and, mainly, the DQI, the latter without differing from the application of Plennan ${ }^{\circledR}$. Low development and very large seedlings can affect the transplant, damaging the final canopy and production. The results obtained in this work reinforce the need for nutritional supplementation of the substrate for the production of Cambuci pepper seedlings since the plants from control treatment with only the nutrients present in the substrate did not develop adequately until the end of the cycle.

\section{Conclusions}

The Hoagland and Arnon nutrient solution provided better traits to produce quality Cambuci pepper seedlings, considering all the variables analyzed.

\section{Acknowledgments}

The authors would like to thank Claudio Roberto Ribeiro da Silva for preparing the nutrient solution used in this research, and CAPES and CNPq for the scholarships.

\section{Bibliographic References}

ABCSEM, 2014. Associação Brasileira de Comércio de Mudas e Sementes. http://www.abcsem.com.br/releases/2614/abcsem-na-hortitec2014 (acessado 16 de abril de 2020).

Albrecht, E., Zhang, D., Saftner, R.A., Stommel, J.R., 2012. Genetic diversity and population structure of Capsicum baccatum genetic resources. Genetic Resources and Crop Evolution, 59, 517-538. DOI: 10.1007/s10722-011-9700-y.

Benício, L.P.F., Reis, A.D.B., Reis, A., Rodrigues, H., 2011. Diferentes concentrações de biofertilizante foliar na formação de mudas de quiabeiro. Revista Verde, 6(5), 92-98.

Bezerra, F.C., 2003. Produção de mudas de hortaliças em ambiente protegido. Fortaleza, Embrapa Agroindústria Tropical, 22 p. (Documentos, 72).
Cardoso, A.I.I., Piedade, M.B.S., Rodrigues, J.M., Ricardo, L.E., 2017. Produção de couve chinesa em função da fertirrigação nitrogenada e potássica nas mudas. Horticultura Brasileira, 35(4), 512-518. DOI: 10.1590/s0102053620170407 .

Carvalho, S.I.C., Bianchetti, L.B., 2008. Botânica e recursos genéticos, in: Ribeiro, C.S.C., Lopes, A.C., Carvalho, S.I., Henz, G.P., Reifschneider, F.J.B., (Ed.). Pimentas Capsicum. Embrapa Hortaliças, Brasília, p. 39-54.

Castellane, P.D., Araújo, J.A.C., 1995. Cultivo sem solo hidroponia, terceira ed. FUNEP, Jaboticabal.

Ciavatta, S.F., Silva, M.R., Simões, D., 2014. Fertirrigação na produção de mudas de Eucalyptus grandis nos períodos de inverno e verão. Cerne, 20(2), 217-222. DOI: 10.1590/01047760.201420021374.

Costa, E., Jorge, M.H., Schwerz, F., Cortelassi, J.A.D.S., 2013. Emergência e fitomassa de mudas de pimentão em diferentes substratos. Revista Brasileira de Ciências Agrárias, 8(3), 396-401. DOI: 10.5039/agraria.v8i3a2428.

Costa, M.P.S.D., Rêgo, M.M., Silva, A.P.G., Rêgo, E.R., Barroso, P.A., 2016. Characterization and genetic diversity of pepper (Capsicum spp) parents and interspecific hybrids. Genetics and Molecular Research, 15(1), 1-12. DOI: 10.4238/gmr.15027652.

Cunha, A.R., Martins, D., 2009. Classificação climática para os municípios de Botucatu e São Manuel, SP. Irriga, 14(1), 111.

Dickson, A., Leaf, A.L., Hosner, J.F., 1960. Quality appraisal of white spruce and white pine seedling stock in nurseries. The Forestry Chronicle, 36(1), 10-13. DOI: 10.5558/tfc36010-1.

Diniz, K., Guimarães, S.T.M.R., Luz, J.M.Q., 2006. Húmus como substrato para a produção de mudas de tomate, pimentão e alface. Bioscience Journal, 22(3), 63-70.

Filgueira, F.A.R., 2008. Novo manual de olericultura: agrotecnologia moderna na produção e comercialização de hortaliças, segunda ed. Viçosa, UFV.

Fonseca, R.M., Lopes, R., Barros, W.S., Lopes M.T.G., Ferreira, F.M., 2008. Morphologic characterization and genetic diversity of Capsicum chinense accessions along the upper Rio Negro - Amazonas. Crop Breeding and Applied Biotechnology, 8, 187-194.

Govindarajan, V.S., Salzer, U.J, 1986. Capsicum - produção, tecnologia, química e qualidade. Parte II. Produtos processados, normas, produção e comércio mundial. Critical Reviews in Food Science and Nutrition, 23(3), 207-288. DOI: $10.1080 / 10408398609527426$.

Hoagland, D.R., Arnon, D.I., 1950. The water-culture method for growing plants without soil. California Agricultural Experiment Station, 31 p. (Circular, 347).

Kerbauy, G.B., 2013. Fisiologia vegetal, segunda ed. Rio de Janeiro, Guanabara Koogan.

Maciel, T.C.M., Silva, T.I., Oliveira, A.F.D., Marco, C.A., Ness, R.L.L., 2017. Substrato à base de pequi (Caryocar coriaceum) na produção de mudas de tomate e pimentão. 
Revista de Agricultura Neotropical, 4(2), 1-9. DOI: 10.32404/rean.v4i2.1551.

Marcos-Filho, J., 2015. Fisiologia de sementes de plantas cultivadas, segunda ed. Londrina, ABRATES.

Menichini, F., Tundis, R., Bonesi, M., Loizzo, M.R., Conforti, F., Statti, G., Cindio, B., Houghton, P.J., Menichini, F., 2009. Influence of fruit ripening on phytochemical content and biological activity of Capsicum chinense Jacq. cc Habanero. Food Chemistry, 114(2), 553-560. DOI: 10.3390/agronomy10020252.

Minami, K., 2010. Produção de mudas de alta qualidade, primeira ed. Piracicaba, Degaspari.

Miqueloni, D.P., Negreiros, J.R.S., Azevedo, J.M.A., 2013. Tamanhos de recipientes e substratos na produção de mudas de pimenta longa. Amazônia: Ciência e Desenvolvimento, 8(16), 81-92.

Nadai, F.B., Menezes, J.B.C., Catão, H.C.R.M., Advíncula, T., Costa, C.A., 2015. Produção de mudas de tomateiro em função de diferentes formas de propagação e substratos. Revista Agro@mbiente On-line, 9(3), 261-267. DOI: 10.18227/1982-8470ragro.v9i3.2348.

Oliveira, F.A., Medeiros, J.F., Linhares, P.S.F., Alves, R.C., Medeiros, A., Oliveira, M.K., 2014. Produção de mudas de pimenta fertirrigadas com diferentes soluções nutritivas. Horticultura Brasileira, 32(4), 458-463. DOI: 10.1590/S0102053620140000400014.

Oliveira, J.F., Alves, S.M.C., Neto, M.F., Oliveira, R.B., 2012. Efeito da água residuária de esgoto doméstico tratado na produção de mudas de pimenta Cambuci e quiabo. Enciclopédia Biosfera, 8(14), 443-452.

Oliveira, J.M., Rezende, R., Freitas, P.S.L., Maller, A., Hara, A.T., Santos, F.A.S., 2016. Fertirrigação na cultura da rúcula
(Eruca sativa MILLER) conduzida em ambiente protegido. Irriga, 21(3), 438-448. DOI: 10.15809/irriga.2016v21n3p438448 .

Pasa, M.C., Zurra, R.M.O., David, M.D., 2017. Múltiplos olhares sobre a biodiversidade, in: Pasa, M.C., David, M.D., (Orgs.). Caminhando com os ribeirinhos pela Amazônia. AM, Brasil. EdUFMT, Carlini \& Caniato, p. 537-548.

Salisbury, F.B., Ross, C.W., 2013. Plant Physiology, fourth ed. Cengage Learning, United States.

Santos, C.B., Longhi, S.J., Hoppe, J.M., Moscovich, F.A., 2000. Efeito do volume de tubetes e tipos de substratos na qualidade de mudas de Cryptomeria japonica (L.F.) D. Don. Ciência Florestal, 10(2), 1-15. DOI: 10.5902/19805098466.

Silva, L.P., Oliveira, A.C., Alves, N.F., Silva, V.L., Silva, T.I., 2019. Uso de substratos alternativos na produção de mudas de pimenta e pimentão. Colloquium Agrariae, 15(3), 104-115. DOI: 10.5747/ca.2019.v15.n3.a303.

Silva, P.N.L., Souza, L.G., Redigolo, M.V.N., Cardoso, A.I.I., 2018. Produção de brócolis em função das doses de nitrogênio e potássio na fertirrigação das mudas. Revista de Agricultura Neotropical, 5(4), 61-67. DOI: 10.32404/rean.v5i4.2448.

Souza, E.G.F., Barros Júnior, A.P.B., Silveira, L.M., Santos, M.G., Silva, E.F., 2013. Emergência e desenvolvimento de mudas de tomate IPA 6 em substratos, contendo esterco ovino. Ceres, 60(6), 902-907. DOI: 10.1590/S0034737X2013000600020.

Zimmer, A.R., Leonardi, B., Miron, D., Schapoval, E., Oliveira, J.R., Gosmann, G., 2012. Antioxidant and antiinflammatory properties of Capsicum baccatum: traditional use in the scientific approach. Journal of Ethnopharmacology, 139(1), 228-233. DOI: 10.1016/j.jep.2011.11.005. 